https://doi.org/10.31516/2410-5325.072.09*

UDC 75.041.5.071.1(479.24)Алієв(045)

F. Mammadova

Nakhchivan Branch of ANAS, Institute of Art, Language and Literature, Nakhchivan, Azerbaijan

\title{
ARTISTIC FEATURES OF PORTRAIT WORKS OF PEOPLE'S ARTIST HUSEYNGULU ALIEV
}

\section{F. Mammadova. Artistic features of portrait works of people's artist Huseyngulu Aliev}

Achieving a realistic view of the image on canvas or paper is a key requirement of the portrait genre. Since the establishment of the professional school of painting, the portrait has attracted the attention of Azerbaijani artists and has been widely used in their work. Thus, in our miniatures of the Middle Ages, as well as among the paintings created in the XIX-XXI centuries, you can find beautiful, eyecatching portraits with high artistic value. Thus, the portrait has always occupied one of the main places in Azerbaijani painting. Of course, the main object of the portrait genre is a person, so its spiritual world and position in society is the main theme of fine art. For many years, portraits in Azerbaijani painting have been mainly dedicated not only to creative intellectuals, but also to workers, collective farmers and labor pioneers. In portraits, on the one side, there is a generalization of images, and on the other side, there is a more democratic approach to the selection of models. The characters in the portraits are close people, friends, relatives of the artists, or strangers who are attracted only by their appearance. Elements of painting in the human image of Azerbaijani artists attract attention: color, texture experiment, spatial elements, format, etc. It is known that in order to create a realistic portrait, artists must master the perception of emotions in a person's environment, as well as master the art of realist painting. Throughout the development of the portrait genre, artists are engaged in research, trying to convey the true image of a person in an objective way. In the portrait genre, the image of the century was clearly visible. In the portraits of Azerbaijani artists, generalized, energetic, strong images are often replaced by psychologically complex characters. There is a growing interest in the spiritual world of images, the tendency to reach the depths of thought and intellect, to create a portrait with a rich spiritual content. Portraits created by Azerbaijani artists in modern times differ in their main features, such as deep spirituality and strict intellect.

Keywords: portrait, image, Azerbaijan, Nakhchivan, artist, Huseyngulu Aliev, monumentality, rhythm, color, light and shadowe.
Ф. Маммадова. Художні особливості портретних робіт народного художника Хусейнгулу Алісва

Актуальність. Роботи Х. Алієва відзначаються вдалими різкими кольоровими переходами, тональними плямами, світловими ефектами, миттєвими відблисками у формуванні динамізму, а також унікальною творчою позицією художника в поєднанні з різними композиційними структурами. Тому розгляд його творчості нині надзвичайно важливий.

Мета статті - дослідити художні особливості портретних робіт народного художника Х. Алієва.

Методологія. Під час дослідження використано метод порівняльного аналізу.

Результати. У творі «Молла Насреддін», який зараз зберігається в приватній колекції в Норвегії, художник втілив глибоке вираження динамізму в композиції: як жорсткість рухів, раптові стрибки, так і контрастний перехід кольорів від світлого до темного та навпаки. Серед графічних прикладів, створених у згаданий період, унікальна композиція твору «Дороги» привертає увагу аудиторії. Художник оспівав далекий шлях, сповнений руху великої кількості людей, які ідуть в одному напрямку. Марш людей, котрі долучаються до руху на порожньому фоні, виражає іх спільне мислення та волю. Тут художник успішно впровадив масове мислення.

Цікава та жартівлива композиція художника в його карикатурі «Мистецький мученик», створена приблизно 20 років тому. Сценічний гімн виступу довговухого, котрий тримає в руках бубон, у художній формі чітко виражає задум митця. Вирішення символічного значення, наданого художником деяким сценам життя, використовуючи народні вислови в унікальній композиційній структурі, дозволяє оцінювати творчість художника, подаючи його в різній формі в кожному творі. Наприклад, у своїй роботі 2001 р. «Вони роблять старий Місяць зіркою» він похвалив астролога, що сидів на орлі з відрізаною головою і перетворював старий місяць на зірки на небі. Художник мав на увазі людей, які були невдячними та відступниками.

Практичне значення. Роботи Х. Алієва надзвичайно цікаві й важливі для всіх дослідників, художників завдяки глибокому вираженню дина-

* This work is licensed under a Creative Commons Attribution-NonCommercial-ShareAlike 4.0 International License. 
мізму в композиції. Молоді митці можуть використовувати його живописну форму та методи у своїй діяльності.

Висновки. У результаті дослідження можна відзначити, що в роботах Х. Алієва художні перебільшення, різні оцінки подій або керування ними відповідно до змісту твору становлять неординарні творчі відкриття. Наприклад, художник, який перетворив фрагмент всесвітньовідомого скульптора О. Родена «Мислитель» на картину, показав, як дві змії стикаються, б'ються і намагаються отруїти одна одну, водночас вони заглиблені в роздуми про світ події. Тут різкість художнього узагальнення в такій складній сцені, як знищення тієї самої статі, змушує глядача замислитися.

Ключові слова: портрет, образ, Азербайджан, Нахчиван, художник, Хусейнгулу Алієв, монументальність, ритм, колір, світло і тінь.

Introduction. People's Artist of the Republic of Azerbaijan, member of the Union of Artists of Azerbaijan and the Union of Theater Figures, well-known master of brushes and pencils, talented artist and sculptor Huseyngulu Aliev has a wide range of creativity. Portrait painting attracted the artist seriously and occupied one of the main places throughout his productive career. People's artist Huseyngulu Aliev's paintings, especially portraits, not only give a different look to the image, but also bring to life the thoughts and ideas, details and ideas that complement it. These works are distinguished by the originality of his creative imagination, monumentality, rhythm and color, style of feeling. In Huseyngulu Aliev's works in the genre of portraits, along with cartoons substantiating the political, social or creative activities of famous people, we also witness a psychological approach that emphasizes their character and originality. While the artist usually uses descriptions of details and elements that enliven the creative environment, the masterpiece has managed to convey his personal attitude and respect to the painting by trying to express the characters of the image (Akhundlu, 1999, p. 1).

The artist has interesting works in the genre of portraiture: the color of the portrait of the great writer Hussein Javid was chosen in accordance with the mood of the image. In the work, Javid's raised eyebrows, facial expressions, and the tense position of his hand resting on the table express his inner concern arising from the sociopolitical injustice of the time. Numerous works such as "Midhat", "J. Mammadguluzadeh", "J. Mammadguluzadeh and his son Anvar",
"Salman Mumtaz", "J. Mammadguluzadeh with family members", "Ahmad Javad", "Azim Azimzadeh", "Y. V.Chamenzaminli" kept in the Nakhchivan Literature Museum named after Jalil Mammadguluzadeh attract attention as a beautiful result of the artist-sculptor's creative pursuits. In these portraits, the artist emphasizes a number of features that characterize the personalities he depicts in order to show the inner world of the images. In these works, the psychological depth, simplicity of the images, the organic connection of the external features with the strong interpretation of the inner world are clearly felt. Graphic portraits of professors Abbas Zamanov, Aziz Sharif, M. J. Jafarov, poets Mammad Araz, Khalil Rza and the poet's graphic illustration "The world of Almaz Ildirim" displayed in the museum show that the artist was well acquainted with the complex technical requirements of this genre (Bayramgizi, 2011, p. 7).

The radiant face of the world-famous statesman and politician, national leader Heydar Aliev comes as a red line in the work of the artistsculptor. He not only achieved the resemblance of portraits in his paintings and bas-reliefs and busts made of various materials, but also gave the spiritual world of the Great Leader. The monumental monument of Koroglu, erected in Nakhchivan in 1988, is undoubtedly one of his most successful works. With a mad roar on the back of the legendary Girat, who rose to the throne with a sword in his hand, Koroglu called on the brave men of Chanlibel to attack the enemy.

In the portrait of the "National leader" created by the People's artist with a skillful brush, the struggle of the prominent statesman Heydar Aliev to promote the independent Azerbaijani state in the world is expressed in talented selected details. The image of our national flag waving over his head and the walking earth fully reflects the fighting spirit of the national leader and his world fame. The artist, who also included the portrait praising of his contemporaries, was able to skillfully achieve an accurate expression of typological characteristics in the creation of each character. We see the confirmation of the above in the example of painting created in 2009 by the vice-president of ANAS, academician Isa Habibbayli. In the portrait of the famous scientist, the artist painted his face inside the office, behind the chair, as if he turned his face to the people who was listening to him. 
Here, the artist, who skillfully uses space and image synthesis in the purposeful solution of other elements, successfully presented the vital activity of the image, gave a joint portrait of the great personalities of our people Heydar Aliev and Ilham Aliev on the back wall. In the left part there is a telephone belonging to the state, a small statue, and in the right part there is a description of a book with the flag of our state on it. The emphasis on seriousness in the artistic expression of the scientist in the center presents the public activity of the image, its deep responsibility for its work to the audience in full. The suit, dressed in a neat blue-gray color, also created harmony in the work, which was dominated by blue tones.

In the painting dedicated to the Honored artist of Azerbaijan Telman Abdinov, created in 2010, which clearly shows the creative personalities and their peculiarities, we also come across an artistic reflection of originality and individuality. Thanks to this nuance, the artist, who did not include other details in the hymn of the creative characteristic environment with the expression of the world of colors born from the artist's world, was able to achieve a full image hymn. These signs are resolved by the artist's skill in his optimistic, loving faces and deep looks. The spots cast on the dark green background with the skillful use of shadows and light nuances contrast the viewer with the striking portrait of the image. T. Abdinov, wearing a black cap, looks sideways and presents a creative image of himself, trying to share his love of life with everyone. The wide white scarf on the dark-colored jacket contrasted with other shades and increased its value, which was of great importance in achieving harmony in the work (Aliev, 2002, p. 122).

Along with Huseyngulu Aliev's portraits dedicated to artistic images and celebrities, there are also family paintings created by him with love and respect. One of them is his painting "My father and mother", created in 1983, which attracts attention with its sincerity. There are traces of the artist's great love on the canvas. On the darker surface of the background, the bright light nuance is reflected in the full back of the images, as if their wise faces were especially illuminated.

The artist increased the moral value of the work by singing real portraits of both parents, especially appreciating their depictions of elements of national values. It first finds its expression in the form of clothing. The father was given a black steamer hat and a brown shirt with a short neck under the jacket. By reviving his mother with a white robe on his head, the artist was able to bring both reality and national values to the fore. The red shirt on the mother's shoulder creates a contrast of colors, allowing the harmonious expression to be more pronounced. The successful combination of color values such as white, red, dark brown, and black once again makes portraits particularly theoretical.

Research. As a result of Huseyngulu Aliev's deep psychological approach to his works in the portrait genre, we are witnessing a clear personal attitude to the image. One of the brightest examples of such works in the painting "Portrait of Academician Zarifa Alieva" is a flower with a scientist-mother smile, which complements each other in the interior.

The bright facial expression of the image on the painting, which is mostly solved in dark shades, seems to give a brightness to the meaning and value of the whole work. In the right part of the work, dark red and purple flowers are placed in a blue vase on the table in front of the bookshelf. In the left part, Zarifa Alieva's polite expression, which looks a little to the side, reflects her character and deep world with great skill. The wide white neckline of the shirt, worn over a black jacket, created a special opportunity for a bright facial expression. The brilliance of simple pearls hanging from his neck has the same purpose. The nuance of combining a woman's seriousness with delicate taste is also noteworthy here.

In the work "My sister Zeynab" we see the emergence of such dynamism without the use of colors that create a sharp contrast as a result of the assessment of image and space, the artistic solution of national elements, without damaging the interest of the work, on the contrary, its value. The artist was able to achieve this thanks to the skillful use of light and dark shades of black and white, the relationship of light and shadow. The table reflects the home environment. Light spots cast on the dark gray shades of the back wall do not allow the painting to create a pale image. However, in white, the wall painting with images depicts the dynamics of space, creating a contrast that illuminates the whole room. The tradition of a copper bowl nationality placed on an ancient cupboard halfway up the wall proves its value in the work, at least in the case of a 
white shawl that extends from the woman's head to her shoulders. Standing on her feet, the image crosses its arms and looks quietly sideways. In the portrait of the artist's sister, who recreates the image of a simple Azerbaijani woman, traces of sincerity and caress are clearly reflected in her facial features (Aliev, 2008, p. 98).

In the painting "Portrait of my daughter", in addition to creating the characteristic features that are familiar to the image, he also solved it within the framework of his personal love for her. The artist's ability to express the feelings and sensibilities expressed in this work can be assessed as a skill to demonstrate mastery. For example, in the above-mentioned painting, the portrait is depicted with colorful meadow flowers in her hands. Here, too, feminine elegance is especially evident. Again, the use of bright spots on a dark blue background confirms its importance in the whole composition. Her hair, which reaches to her shoulders, combines elegance and aesthetics with delicate jewelry on her ears and neck. The blue scarf thrown over the burgundy dress not only contrasts, but also emphasizes the lyricism of the painting, creating harmony in the colors of the flowers.

The use of light spots in the contrast of dark colors creates a contrast between them and increases the value of the work. In the expression of the image with a bright face, we encounter a bright expression of the inner world of a more serious character, which can again be explained as the creation of a characteristic, skillful artistic solution in revealing the inner world, thanks to the artist's precise psychological approach.

In the portrait hymn dedicated to the grandson of the artist "My Leyla", the artist tried to solve the artistic purity of the child's world by giving it surrounded by lilacs, greenery and blossoming flowers. A background that extends into perspective, such as glass brightness, confirms this. Giving a little girl in a white shirt, while the flowers contrast with the bright, colorful colors, on the other hand, allows you to exaggerate the purity. The predominance of mostly green tones in the right part of the table plays a special role in making the image more interesting by contrasting the colors of the left part with lilac flowers.

The sincerity, naturalness and vitality of the work is revealed by the fact that the image of the image behind the large green leaves in the front part is reflected in the world, and the artist captures this moment and transfers it to the canvas. The images attract the viewer's attention by creating a dynamism in the painting by giving dark and light spots on the cement floor. The play of light and shadow in the work, the brightness that illuminates the facial features of the little girl, makes the audience feel the high spirits and optimism that prevail in the spirit of the painting. The same can be said about the portrait of Huseyngulu Aliev dedicated to his wife. The image of a woman, given among the motifs of nature, unlike other works, looks forward with its eyes cut out under the influence of sunlight. The image dissolved in the orchard allows the portrait to attract attention by contrasting it with the dress in white and blue against the background of greenery and green-yellow fruits.

The humility and sincerity in the face of a woman holding a red flower in one hand was brushed with great love. Neatly combed short black hair on the back makes the radiant expression of the radiant face even clearer. White pearls around the neck increase this sensitivity. The masterful singing of the great influences that the artist gives to the work with a small nuance is confirmed by this type of nuances. For example, giving a small red flower in the hands of the woman we are talking about, in addition to the contrast created by this color, which is not present in any part of the picture, expresses her love and affection in the picture on the same level.

If we pay attention to Huseyngulu Aliev's portraiture, we can see that he sometimes achieved this in his bright expression of character through light and dark shades of colors, as well as light and shadow games, but in many cases we see that he gained these sensitive relationships by color contrast. For example, the artist's "Portrait of a woman" painting, created in 2016, is a sharpness born of grief, it should be noted that the artist, who used tonal spots in the expression of stiffness expressions, was able to make this sharp characteristic more prominent by contrasting it with the successful combination of contrasting color values such as blue, black and red at the same time, it is undeniable that the color matching is correct in creating a harmonious expression (Ahmadova. 2019, p. 259-264). The black spot tones on the red color in the background are mainly at the bottom of the table, which helps to balance the image by matching it with the black shades. The 
reddish, slightly warmer shades of orange on the back of the hair serve the same purpose on a red background. A wide blue scarf with a bright blue tone over the neck in warm shades eliminates its aggression, creating a coolness throughout the work.

It is interesting that Huseyngulu Aliev also painted his self-portraits within the composition. In those self-portraits, we see the People's artist together with his family members, grandchildren and art friends. Creating compositional paintings, as well as portraiture, reflects not only the artist's life, nature and man, but also demonstrates the ability to express a new idea each time. In this sense, the fact that the People's artist called the painting dedicated to the founder of Azerbaijani romanticism Hussein Javid "Compositional image of Hussein Javid" shows that he was aware that he also created portraits on the basis of composition. In our opinion, the direction of creating compositions in paintings of different genres is one of the distinctive features of Huseyngulu Aliev's art.

The idea of the sculptor to the spectator is simple and concise at the tombstone of Bahruz bey Kangarli in Nakhchivan, the founder of realist painting in Azerbaijani painting. He was able to create the view of the artist with characteristic lines (Habibbeyli, 2019, p. 10-11).

The image of the genius has been repeatedly addressed by many artists. Although the uniqueness of each artist, his individual creative style, no matter how self-evident it is, the only thing that unites all these portraits is the reflection of the love and power of the great man, the source of pride of our people. For example, People's artist Sakit Mammadov's work dedicated to the glorification of the great political figure Heydar Aliev, we can note that the image given inside the cabinet fully reflects his care and love for the people in his solemn gaze. Or in the painting created by the prominent artist, People's artist Tahir Salahov in 1984, the great leader's brilliant expression is reflected in his gaze on the audience of the great, invaluable love of the people hidden in his heart. In this work, which belongs to the work of Huseyngulu Aliev, along with this love and care, we come across an artistic reflection of a great figure who looks to the future with confidence. The image of the genius, who proudly waved the Azerbaijani flag all over the world in the work, mostly in shades of blue and blue, also clearly reflects the artist's personal attitude, endless respect and esteem (Ibrahimova, 1982, p. 1).

In general, the picture of the Great Leader Heydar Aliev, created in 2011 together with the Chairman of the Supreme Majlis of the Nakhchivan Autonomous Republic, Mr. Vasif Talibov, attracts attention with its sincerity. An interesting nuance in the work is that the mutual images are reflected in an exhibition. A part of the green wall enlivens the impression of space with the artistic expression of various works hanging on it. The images of Heydar Aliev and Vasif Talibov, standing side by side and expressing a sense of pride and pride, are presented in front of his theoretically interesting work with a unique representation of the map of Azerbaijan on a single table. Thus, the artist paid special attention to the description of the content of the work, increasing its value. The map is more attractive in white on dark shades, with flowers and blossoms. The great leader is showing his inner love in the same way by looking at him with a smile. In the real portrait of the chairman on the left, his sense of pride from this encounter is vividly expressed. The dynamism in the spirit of the work is resolved in the expression of a vivid impression, such as the genius leader extending his left hand a little forward and expressing his attitude.

The solution to dynamism can also be seen in the full coordination of colors. The darker shades of the lower part open up a bit towards the upper part, once again confirming the artistic solution of the painting in a striking way. In 2011, in the portrait work dedicated to the Chairman of the Supreme Majlis of the Nakhchivan Autonomous Republic, Mr. Vasif Talibov, his seriousness and sincerity were skillfully solved in the image depicted on a dark background. The artist gave an artistic explanation of the political and social activity of the person given in the work, as well as his proud and humble position worthy of an Azerbaijani citizen with psychological accuracy. For all this, the artist theoretically attracts the brightest embodiment of sincerity by combining the style of clothing of the image with close tones on a dark background, as well as this color scheme, which allows facial features to appear brighter, as well as achieving a higher resolution. The image of a neat white shirt and a bright blue tie, which enhances this effect, was achieved by the artist's skillful use of light rays. Glancing to the side, facial features that express positive energy are 
especially striking in their brightness. Although the work is close to traditional portraiture, it shows the artist's ability to create an accurate character in the emergence of individuality by emphasizing internal psychology (Nakhchivan encyclopedia, 2005, p. 203).

Presenting the portrait of Jalil Mammadguluzadeh together with Nariman Narimanov was perfect in terms of depicting his personality in connection with his time and historical figures. The painting, preserved in the Museum of Literature, together with the great playwright Jalil Mammadguluzadeh, socio-political figure, writer, publicist, doctor Nariman Narimanov, depicts anxious, caring faces who think about the future of the people of both characters. The artist, who was able to successfully combine the synthesis of man and space, considered it expedient to solve the shelves where the books are placed, in a serious and creative space with a small fragment on the wall. The brown-toned tablecloth on the round table contrasted with the white and blue notebooks on top of it, highlighting the bold image.

In the work, where high intelligence is solved with psychological precision, Mirza Jalil and Narimanov, sitting on their feet, turn their faces to the audience and express their concerns stemming from the love of the people for their deep inner worlds. In general, Huseyngulu Aliev repeatedly addressed the topic of Jalil Mammadguluzadeh with love, each time reviving the life of the great writer with different experiences. Among them are two different works created in 1990 and preserved in the Museum of Literature in Nakhchivan. In the first painting, the artist tried to revive the spiritual world of the image with the language of special artistic description, as well as the current psychological situation presented by the moment of description, the sensitivity of that moment (Aliev, 2001, p. 1). The work is interesting for its contrast of colors, the use of dark tones of calm colors, as well as its deep psychological power. The fragment seen from the half-open window behind the curtain conveys the "color" of Mirza Jalil's time, world and life in a vivid form. Here, the artist conveys to the audience the reality of the work by giving a small fragment of an ancient architectural structure, a unique singing of human figures behind an arched door. Jalil Mammadguluzadeh, revived in the style of clothing belonging to the intelligentsia of the time, leans his book on the table and stares at his audience. In this way, the artist Mirza Jalil pointed to the depth of the world, the great and valuable heritage left to us.

Another painting depicts Jalil Mammadguluzadeh's son Midhat. Years later, in the current scene, the little Midhat, who still needs the care of a child next to his father, would gladly play the role of Jalal in his father's famous drama "The Dead". In the presented work, he encounters a sincere family picture of the artist in his portrait with his father, little Midhat, who expresses the signs of talent and talent in his intelligent eyes. In the painting of black and white, we see the sensitivity achieved through lines, precise psychological expressions. It was given during his years of high school education with one hand on his belt. The great personality Jalil Mammadguluzadeh, in one form, with his staff in one hand and his son's back in the other, embodies both the genius genius and the care of an ordinary father in very realistic forms (Ali Maclis, 2005, p. 19).

It is interesting that the sensitivity in the work is achieved not by colors, but by a deep artistic solution of the nuance of light and shadow. Here, the artist tried to arouse the interest of the audience by directing the light mainly on the facial features of the images. The animated expressions, highlighted by the dark shades of the background and the form of clothing, create a sharp contrast and increase the value of the work.

The theme of Hussein Javid, which Nakhchivan artists appeal to with great love, has been presented several times in Huseyngulu Aliev's works in different compositions. The artist, who showed an endless love for the deep world of the great playwright and his invaluable literary heritage, presented a portrait of the great writer in a different composition in his work in the graphic genre created in 1993. Deep, psychological facial features are reflected in real forms in the characteristic statement full of care born from the anxious world with his eyes fixed on the side of his glasses (Azertag, 2019, p. 1). The chaos, confusion, ripples, and whirlwindlike artistic expressions created by the linear expressions in the background reflect the pains, tremors, and storms hidden within this calm, humble face in artistic forms. In the center, the harsh rays of the sun fall on the world, the 
attempts of the blacks to come to power trying to block it ... and so on. is a clear example of all this. By placing the weight mainly on the left side, only the mixed line expressions on the right side and shading of the portrait falling on them attract the attention of the audience with their moving, dynamic compositional structure with the same purpose (Mirzazadeh, 1982, p. 1).

In another oil portrait of Hussein Javid painted on canvas in the same year, in contrast to the previous work, we find a calm environment and image, far from aggression. The subtle rays of blue light falling from the window, which illuminate the space, which is mainly dark, solve the romanticism and lyricism of the whole world, which is characteristic of the writer's world. Hussein Javid is depicted in plain clothes with his hands crossed and leaning on a table. Here, too, it was considered expedient not to bring to the fore a deep, painful, loaded inner world, but to revive a more restrained, wise image of a somewhat calm, inwardly comfortable image.

The light effects with tonal spots on the wall provide an appropriate combination of image and spatial synthesis, expressing this sensitivity in a more pronounced, equally calm tone. Hussein Javid is presented in a simple blue shirt. However, despite the contrasting combination of colors, we can note that the author successfully uses calm color expressions in the singing of appropriate, calm and comfort.

For example, a portrait of Mahammadaga Shahtagli, an intellectual of the early twentieth century and editor of the "Sharqi-Rus" newspaper, created in 2002 and preserved in the Nakhchivan Museum of Literature (Sadikhova, 2011, p. 12). The assistant artist, who did not include additional details, was able to fully recreate the real features of the intellectual, who looked at his audience with a humble and optimistic look. Contrasting shades on the table, dominated by brown tones, seemed to illuminate the radiant face of the portrait. The image on the background in warm shades of plain brown is reflected in a dark jacket and a light white shirt, which serves the purpose of the artist. His graying beard, neatly combed hair, humble features, sincerity and high intelligence reflect the artistic image of Mahammadagha Shahtakhtili (Мамедова, 2020, p. 84-87).

Or the portrait of the Azerbaijani enlightener, pedagogue, poet, publicist, great thinker Mammad Taghi Sidgi can be given as a vivid example. The artist was able to present to the audience all his sincerity in the artistic expression of this rich image, which carries the endless love and affection for his people. The presentation of appropriate details of the uniform of intellectuals of the early twentieth century gives a sense of the native and sincere spirit of the work. In reviving the artistic image of Mohammad Taghi Sidgi, who wore a flat hat, a straight neck and a closed jacket, the artist considered it expedient to reflect his views by looking at unknown distances (Sadikhova, 2019, p. 154). Contrary to the anxious and somewhat sad expressions in the cartoons, it revives the artistic image of an intellectual who carries the pain of his people as his personal pain. In a more effective way of reflecting this sensitivity, the artist enlivened the green-yellow background with the delicate light of a candle. The candlelight from the right illuminates the painting upwards, creating a lyrical-romantic impression that dominates the spirit of the work in accordance with the characteristic image depicted (Singer, 1976, p. 149).

The bright face of $\mathrm{V}$. Ahmadov, one of the hundreds of martyrs of our people, protected in a private collection in Nakhchivan, is reflected against the background of the waving Azerbaijani flag. By giving place to the values of light color, the artist tried to express this purity, inviolability, heroism in its brilliance. It is impossible not to feel the deep respect and esteem of Huseyngulu Aliev to the soul of the martyr, who tries to express deep characteristics in the hymn of the fearless, brave face. The artist, who skillfully managed to generalize the love of the great people for the souls of our martyrs, who always raised the flag of Azerbaijan on a light blue background, in the person of $\mathrm{V}$. Ahmadov, in all seriousness reflected the anthem of the alarm clock and pointed to the future of victory. Part of the waving flag in the work was laid on one shoulder of $\mathrm{V}$. Ahmadov. We note once again that the great hero, who lived with the love of his homeland until his last breath and died for it, managed to get an impressive image of the artist, pointing to this way of life (Veyselli, 2011, p. 107-108) In the painting "Ali usta" by Huseyngulu Aliev, who created portraits of ordinary people with the same enthusiasm, the artist also included the connection of the life and hard work of a hardworking person with the spatial environment. Javid, dressed in an 
apron over the iconic image, puts one hand on the bench, smiles and looks at his audience with optimistic eyes. The artist's goal was to recreate a characteristic face with a pure life, as simple and straightforward (Basin, 1986, p. 20). The blue light from the wooden-framed window gave the work dynamism, saving the work from the frozen style of painting, including the space. While the artist has achieved this sensitivity through more colors in previous paintings, the nuance of being able to achieve that impression by giving an artistic expression of the auxiliary elements in the work is noteworthy. The master, holding a thick worker's glove in one hand, was presented as if he were trying to relax by taking a break from his work, holding the other hand in a comfortable position. The artist captured that moment and skillfully recreated the life in the shop by depicting it. The talented artist was able to attract the attention of the audience with precisely characteristic lines, appealing to different images in many graphic paintings.

As an example of the solution of the characteristic lines of expression presented by the black-and-white contradiction, the "Portrait dedicated to the $60^{\text {th }}$ anniversary of the poet Elman Habib" is a thoughtful discovery of books written by a talented writer as the backbone of his desk (Singer, 1986, p. 200). This painting is an original portrait of the late poet Elman Habib in a very full and meaningful way. Despite the fact that the work does not use artistic means of depiction, such as background, contrasts, nuances of light and shadow, the meaningful picture presented by the full compositional structure attracts the attention of the audience. In the graphic work preserved in the private collection in Nakhchivan, the face of the poet looking at the audience in front of the audience is naturally revived. He sang in a classic suit, holding a pen in one hand, as if he were speaking in a tribune given the use of the rest of the books, which contained meaningful words from his inner world. The tribune begins to widen from the bottom to the top with a series of narrow books. With this arrangement, the artist achieved a harmonious expression in an unusual compositional structure. The fact that the artist's inner world is sometimes solved with the use of auxiliary details, and in many cases only with deep animated expressions, suggests that they were created with great sensitivity.
Conclusion. As a result of the article, we must note that as a result of the deep psychological approach of the People's Artist Huseyngulu Aliev in the study of the artistic features of the portrait genre, we see a clear personal attitude to the images created by the artist. The most vivid example of this is the portrait of the "National Leader", in which the struggle of prominent statesman Heydar Aliev to promote the independent state of Azerbaijan in the world is presented as an expressive hymn of endless love for the genius. It is interesting to see the artist's works of injustice, injustice, and in many cases the most sensitive parts of our ordinary lives, giving their artistic expression and making the viewer think more deeply. The philosophical approach to the subject in different compositions, aimed at the dramatic interpretation of the content with real or unreal forms, creates an existentialist way of thinking of the artist (Singer, 1974, p. 24). Basing on the research, the author got following conclusion: in the portrait work of the artist, the inner world of a person is solved with great sensitivity, sometimes with the use of auxiliary details, and in many cases only with deep animated expressions.

\section{References}

Ahmadova, F. (2019). Genre diversity in paintings of People'sartistHuseynguluAliev.News of Nakhchivan branch of ANAS: Social and humanitarian sciences series, 3, 259-264. [In English].

Akhundlu, Y. (1999). Literary environment in Nakhchivan. Gobustan, 2. [In English].

Aliev Huseyngulu Ali oglu (2002). In Nakhchivan encyclopedia. Baku. [In English].

Aliev Huseyngulu Ali oglu (2008). In Encyclopedia of Jalil Mammadguluzade. Baku: East-West. [In English].

Aliev, A. (2009). People's artist of Azerbaijan Huseyn Aliev. Baku. [In English].

Basin, E. A. (1986). To the definition of the genre of the portrait (based on the material of the Soviet pictorial portrait of the 1960-1970s). Sovetskoe iskusstvoznanie. (Issue 20). Moscow. [In Russian].

Bayramgizi (2011). Afsana The memory of People's Artist Huseyn Aliev was commemorated with deep respect and esteem. Khalg, April 23, 7. [In English].

Habibbeyli, I. (2019). Professional artist and skilled sculptor. 525th newspaper, February 9, 10-11. [In English].

Ibrahimov, A. (1982). The artists of Nakhchivan. Literature and art, November 5. [In English].

"Know me as I am ...". Dedication to the memory of People's Artist Huseyn Aliev. Bizim Asr, 92 (808). [In English]. 
Mamedova, F. A. (2020). Artistic display of the image of a person in the work of Huseyngulu Aliev. Paradigmata poznani, 4, 84-87. [In Russian].

Mirzazadeh, O. (1982). Works of the artists of Nakhchivan. Literature and art, 5 November. [In English].

Nakhchivan patterns: works of artists of Nakhchivan Autonomous Republic (2005). Ministry of Culture of the Republic of Azerbaijan. Baku: Indigo. [In English].

Nakhchivan encyclopedia (2005). (In 2 volumes). Nakhchivan. [In English].

Sadikhova, S. (2011). The world of colorful colors: People's artist Huseyngulu Aliev proved himself as a master in various fields of fine arts. Culture, May 25, 12. [In English].

Sadikhova, S. (2019). The art world of People's artist Huseyngulu Aliev: album-monograph. Nakhchivan: "Ajami” Publishing and Printing Union. [In English].
Veyselli, U. (2011). Diversity of genres and styles in the works of Huseyngulu Aliev. Music world, 2/47, 107-108. [In English].

Singer, L. S. (1986). Essays on the theory and history of portrait. Moscow: Izobrazitel'noe iskusstvo. [In Russian].

Singer, L. S. (1974). Creative problems of modern portrait in easel painting. Hudozhnik, 22-38. Moscow. [In Russian].

Singer, L. S. (1976). Some trends in the development of the image of a contemporary in portrait painting of the 60s-early 70s. Moscow: Sovetskij hudozhnik. [In Russian].

The $70^{\text {th }}$ anniversary of People's Artist Huseyngulu Aliev has been marked. https://azertag.az/xeber/Xalq ressami_Huseynqulu_Alievin_70_illik_yubileyi_ qeyd_edilib-1242049. [In Azeri].

Надійшла до редколегії 22.03.2021 